\title{
Artikel
}

\section{De juridische plicht om euthanasie te bespreken met patiënten met dementie voordat artsen schriftelijke wilsverklaringen kunnen uitvoeren}

Mr. dr. N. (Klaas) Rozemond*

NTS 2020/76

\section{Inleiding: de onbeantwoorde vraag}

Op 21 april 2020 wees de Hoge Raad twee arresten in de spraakmakende zaak van de verpleeghuisarts die het leven beëindigde van een patiënte met dementie. In deze zaak had de rechtsvraag moeten worden beantwoord of de arts mocht besluiten om het leven van de patiënte te beëindigen zonder de patiënte over dat besluit te informeren. De arts voerde de levensbeëindiging uit door een slaapmiddel in de koffie van de patiënte te doen. De arts diende vervolgens een dodelijk middel toe via een infuus waartegen de patiënte zich fysiek verzette, waarna de patiënte werd vastgehouden om te voorkomen dat zij zich verder zou verzetten. ${ }^{1}$

Als dit in algemene zin zou zijn toegestaan, hebben artsen de bevoegdheid om levensbeëindigend te handelen zonder hun patiënten hierover te informeren. Deze

Mr. dr. N. Rozemond is universitair hoofddocent strafrecht aan de Vrije Universiteit Amsterdam.

1. Zie voor de relevante feiten Oordeel 2016-85 van de toetsingscommissie (www.euthanasiecommissie.nl). bevoegdheid moet wel kunnen worden afgeleid uit een schriftelijke wilsverklaring die de strekking heeft dat een patiënt in geval van wilsonbekwaamheid de regie over zijn levenseinde overdraagt aan een arts. Het is echter aan de arts om te beoordelen of een schriftelijke wilsverklaring die strekking heeft en de patiënt wilsonbekwaam is geworden. ${ }^{2}$ De arts moet bovendien vaststellen dat de patiënt ondraaglijk lijdt, maar de arts heeft ook ten aanzien van de beoordeling daarvan een bevoegdheid die slechts marginaal kan worden getoetst. ${ }^{3}$

Het is de vraag of de bevoegdheid van artsen om levens van psychogeriatrische patiënten te beëindigen zonder deze patiënten hierover te informeren juridisch aanvaardbaar is. Opmerkelijk is dat de Hoge Raad in zijn twee arresten van 21 april 2020 geen expliciet antwoord geeft op deze rechtsvraag. In beide arresten ontbreken motiveringen ten aanzien van de tegenovergestelde rechtsopvattingen van het Regionaal Tuchtcollege Den Haag en de rechtbank Den Haag over het wel of niet bestaan van een juridische plicht van de arts om de patiënt te informeren over het voornemen van de arts om het leven van de patiënt te beëindigen. De Hoge Raad gaat wel uitgebreid in op de wijze waarop schriftelijke wilsverklaringen moeten worden uitgelegd en de wijze waarop de zorgvuldigheidseisen van artikel 2 Wet toetsing levensbeëindiging op verzoek en hulp bij zelfdoding (Wtl) moeten worden toegepast. ${ }^{4}$ De Hoge Raad 
laat zich echter niet expliciet uit over de rechtsvraag of een arts de juridische plicht heeft om zijn patiënt te informeren over de voorgenomen levensbeëindiging.

Ik wil in deze bijdrage betogen dat de Hoge Raad ten onrechte niet is ingegaan op deze specifieke rechtsvraag. Ik zal daarbij de algemene overwegingen van de Hoge Raad over de uitleg van schriftelijke wilsverklaringen en de toepassing van de zorgvuldigheidseisen niet bespreken, behalve voor zover deze algemene overwegingen relevant zijn voor de specifieke rechtsvraag of de arts de juridische plicht heeft om de patiënt te informeren over het voornemen om zijn leven te beëindigen. Ik wil in deze bijdrage aan de hand van de specifieke overwegingen daarover in de uitspraken van het Regionaal Tuchtcollege en de rechtbank Den Haag onderzoeken hoe deze specifieke rechtsvraag moet worden beantwoord.

De conclusie van mijn onderzoek zal zijn dat de Hoge Raad het vonnis van de rechtbank op dit specifieke punt had moeten vernietigen en de uitspraak van de tuchtrechter op dit punt had moeten bevestigen. Het belangrijkste argument hiervoor is dat de rechtsopvatting van het Regionaal Tuchtcollege over de juridische plicht om de patiënt te informeren een hecht fundament heeft in gezondheidsrechtelijke en mensenrechtelijke rechtsnormen. Uit deze rechtsnormen volgt dat het voornemen van de arts om het leven van de patiënt te beëindigen, moet worden besproken met de patiënt om de patiënt de gelegenheid te geven om hierover zijn wil te uiten en zelf te beslissen.

De patiënt heeft het recht om zelf te beslissen over zijn levenseinde totdat kan worden vastgesteld dat de patiënt niet langer in staat is tot een redelijke waardering van zijn belangen ter zake van deze beslissing. Of dat het geval is, moet worden beoordeeld in een gesprek met de patiënt over de beslissing om zijn leven te beëindigen waarin de arts de patiënt over deze beslissing informeert. Wanneer in dat gesprek blijkt dat de patiënt niet langer in staat is om over deze beslissing zijn wil te uiten, kan de arts het leven van de patiënt beëindigen op grond van het verzoek daartoe uit de schriftelijke wilsverklaring van de patiënt, mits aan de overige zorgvuldigheidseisen van artikel 2 lid $1 \mathrm{Wtl}$ is voldaan.

De eis van een gesprek met de patiënt waarin de patiënt wordt geïnformeerd over de beslissing om zijn leven te beëindigen, ligt ook besloten in de arresten van de Hoge Raad. Volgens de Hoge Raad moet een onafhankelijke arts met specifieke deskundigheid onderzoeken of aan de zorgvuldigheidseisen van artikel $2 \mathrm{Wtl}$ is voldaan. Tot dat onderzoek behoort een beoordeling van de wilsonbekwaamheid van de patiënt ter zake van de beslissing om zijn leven te beëindigen. Ook deze beoordeling moet worden uitgevoerd door de patiënt over deze beslissing te informeren om hem de gelegenheid te geven daarover zijn wil te uiten. De conclusie van mijn betoog zal daarom zijn dat ook de overwegingen van de Hoge Raad over de vereiste consultatie door onafhankelijke artsen de rechtsopvatting van het Regionaal Tuchtcollege over de informatieplicht van de arts en het beslissingsrecht van de patiënt bevestigen en versterken.

\section{De opvatting van de tuchtrechter}

De Hoge Raad casseerde op twee gronden de uitspraak van het Centraal Tuchtcollege voor de Gezondheidszorg waarin de uitspraak van het Regionaal Tuchtcollege voor de Gezondheidszorg Den Haag werd bevestigd. Volgens de Hoge Raad hebben de tuchtcolleges een te beperkte rechtsopvatting over hun eigen beoordelingstaak in vergelijking met de toetsingscommissies en een te beperkte rechtsopvatting over de interpretatieruimte van artsen ten aanzien van schriftelijke wilsverklaringen. Het Centraal Tuchtcollege volgde de opvattingen van de Regionale Toetsingscommissie Euthanasie in deze zaak, maar had volgens de Hoge Raad een eigen, onafhankelijk oordeel moeten geven over de voor artsen geldende zorgvuldigheidseisen op grond van artikel 47 lid 1 Wet op de beroepen in de individuele gezondheidszorg (Wet BIG). ${ }^{5}$

Het Regionaal Tuchtcollege en het Centraal Tuchtcollege gaven in deze zaak echter wel een eigen, onafhankelijk oordeel over de verplichting van de arts om met de patiënte over euthanasie te praten. De Regionale Toetsingscommissie Euthanasie overwoog in haar oordeel dat de verpleeghuisarts nimmer met de patiënte over euthanasie heeft gesproken en ook niet heeft kunnen spreken. ${ }^{6}$ Uit het oordeel van de toetsingscommissie blijkt dat zij ervan uitging dat de arts dat ook niet hoefde te doen: op dit punt heeft de toetsingscommissie niet geoordeeld dat de arts onzorgvuldig heeft gehandeld. Hierover had het Regionaal Tuchtcollege een oordeel dat afweek van het oordeel van de toetsingscommissie: de arts had wel met de patiënte moeten praten over euthanasie. ${ }^{7}$ Ook over het breken van het fysieke verzet van de patiënte had het tuchtcollege een afwijkend oordeel ten opzichte van de toetsingscommissie. Volgens de toetsingscommissie ging dit te ver en handelde de arts onzorgvuldig, maar dat oordeel kon het Regionaal Tuchtcollege niet onderschrijven. ${ }^{8}$ Het Centraal Tuchtcollege bevestigde deze twee oordelen van het Regionaal Tuchtcollege in zijn door de Hoge Raad gecasseerde uitspraak. ${ }^{9}$ Daaruit volgt dat het Regionaal Tuchtcollege en het Centraal Tuchtcollege hun beoordelingstaak ruimer hebben opgevat dan de Hoge Raad stelt. Zij hebben op deze twee punten niet de toetsingscommissie gevolgd, maar eigen, onafhankelijke oordelen gegeven over het handelen van de arts, zoals de Hoge Raad vereist.

\footnotetext{
R.o. 5 en 6 in HR 21 april 2020, ECLI:NL:HR:2020:713.

Oordeel 2016-85 onder 3. Beoordeling.

R.o. 5.13 in RTG Den Haag 24 juli 2018, ECLI:NL:TGZRSGR:2018:165.

R.o. 5.15 in RTG Den Haag 24 juli 2018, ECLI:NL:TGZRSGR:2018:165.

R.o. 4.9 in CTG 19 maart 2019, ECLI:NL:TGZCTG:2019:68.
} 
Over de verplichting om met de patiënte praten overwoog het Regionaal Tuchtcollege:

'Het College onderkent dat communicatie met patiente op cognitief niveau niet meer tot de mogelijkheden behoorde. Dit betekent echter niet dat verweerster was ontslagen van de verplichting om ten minste te proberen om met patiënte te praten over het concrete voornemen om haar leven te beëindigen en daarbij een slaapmiddel in haar koffie te doen. Niet voor niets is het wettelijk uitgangspunt in de WGBO (artikelen 7:450 en 7:448 BW) en ook in de regelgeving rond dwangbehandeling en dwangmedicatie dat eerst geprobeerd moet worden om de toestemming van patiënt (passend bij zijn bevattingsvermogen) te krijgen. Dat niet is uit te sluiten dat een patiënt in een dergelijk geval niet wil meewerken, is inderdaad een mogelijkheid. Afhankelijk van de aard van de reactie van de patiënt ontstaat dan een nieuwe situatie, die niet altíjd maar soms wél moet leiden tot afstel van het voornemen tot levensbeëindiging. Hoewel dat wellicht onwenselijk is vanuit de optiek van (in dit geval) verweerster die het ondraaglijke en uitzichtloze lijden van patiënte wilde beëindigen, staat daar tegenover dat het uiteindelijk de patiënte is die het recht heeft om over haar eigen leven te beschikken. Dit recht raakt patiënte in beginsel niet kwijt wanneer zij dement wordt. ${ }^{10}$

De verplichting van de arts om met de patiënte te praten over het voornemen om haar leven te beëindigen, geldt blijkens de overwegingen van het Regionaal Tuchtcollege ook bij een duidelijke schriftelijke wilsverklaring. ${ }^{11}$ Ook bij een duidelijke schriftelijke verklaring moet de arts de voorgenomen levensbeëindiging met de patiënt bespreken en moet de arts proberen om daarvoor toestemming van de patiënt te krijgen. Wanneer de patiënt daaraan niet wil meewerken, is dat voor de arts een reden om de levensbeëindiging af te stellen.

Dat betekent dat de twee cassatiegronden van de Hoge Raad met betrekking tot de te beperkte taakopvatting van de tuchtcolleges en de interpretatieruimte van artsen niet van toepassing zijn op de aangehaalde overweging van het Regionaal Tuchtcollege. Het is daarom niet duidelijk waarom de Hoge Raad de volledige uitspraak van het Centraal Tuchtcollege heeft vernietigd waarin dit eigen, onafhankelijke oordeel van het Regionaal Tuchtcollege werd bevestigd. ${ }^{12}$ De Hoge Raad heeft niet gemotiveerd waarom dit zelfstandige oordeel van de tuchtcolleges ten aanzien van de verplichting van de arts om met de patiënte over euthanasie te praten onjuist is. ${ }^{13}$

10. R.o. 5.13 in RTG Den Haag 24 juli 2018, ECLI:NL:TGZRSGR:2018:165.

11. Vgl. het slot van r.o. 5.10 in RTG Den Haag 24 juli 2018, ECLI:NL:TGZRSGR:2018:165.

12. In gelijke zin J.H. Hubben in punt 3 en 4 van zijn noot onder HR 21 april 2020, ECLI:NL:HR:2020:713, GJ 2020/71.

13. Dat geldt ook voor het eigen, onafhankelijke oordeel in r.o. 5.15 van RTG Den Haag 24 juli 2018, ECLI:NL:TGZRSGR:2018:165. Wellicht is hierover een misverstand ontstaan door de bewering in r.o. 4.9 in CTG 19 maart 2019, ECLI:NL:TGZCTG:2019:68 dat de oordelen op deze

\section{De opvatting van de strafrechter}

Wellicht kan de onjuistheid van de rechtsopvatting van het Regionaal Tuchtcollege en het Centraal Tuchtcollege worden afgeleid uit het arrest van de Hoge Raad over het vonnis van de rechtbank Den Haag. In haar vonnis overwoog de rechtbank over de rechtsplicht van de arts om met de patiënte over euthanasie te praten:

'Het is de rechtbank bekend dat in de medische wereld richtlijnen zijn opgesteld over het medisch handelen bij euthanasie waarin het standpunt wordt ingenomen dat de behandelend arts ook bij wilsonbekwamen nog wel moet proberen het standpunt van de patiënt over diens actuele euthanasiewens te verifieren. Dat standpunt is echter, zoals blijkt uit de hiervoor geciteerde wetsgeschiedenis, strenger dan de wet. Wellicht verdient het vanuit een oogpunt van medische zorgvuldigheid aanbeveling zelfs met een persoon die daar de portee absoluut niet meer van kan inzien, te spreken over de actualiteit van zijn of haar, zoals in dit geval, jaren geleden aangegeven en sedertdien regelmatig geactualiseerde stervenswens. De rechtbank vermag de noodzaak daarvan echter niet in te zien, laat staan dat daartoe een juridische plicht bestaat.' 14

De rechtbank verwijst naar de parlementaire geschiedenis van de Wtl. Daaruit blijkt volgens de rechtbank niet dat voor de arts een juridische plicht bestaat om bij wilsonbekwamen hun actuele euthanasiewens te verifiëren. Kennelijk leidt de rechtbank uit de parlementaire geschiedenis ook af dat artsen niet tegen wilsonbekwamen hoeven te zeggen dat zij euthanasie gaan uitvoeren en hoe zij dat gaan doen, en dat artsen ook niet hoeven te proberen om daarvoor toestemming van de patiënt te krijgen.

De rechtbank gaat ervan uit dat de patiënte al voor de opname in het verpleeghuis wilsonbekwaam was geworden. ${ }^{15}$ Daarom had de arts vanaf het moment van de opname de bevoegdheid om het leven van de patiënte te beëindigen op basis van haar schriftelijke wilsverklaring zonder verificatie van haar euthanasiewens en zonder bespreking van het voornemen om haar leven te beëindigen. De Hoge Raad geeft geen expliciete beoordeling

twee punten in lijn met de RTE zijn. Uit een vergelijking van de uitspraken van de toetsingscommissie en het Regionaal Tuchtcollege blijkt dat dat niet het geval is en dat het Regionaal Tuchtcollege op deze twee punten juist afwijkt van de toetsingscommissie. Bovendien geeft het Regionaal Tuchtcollege een zelfstandig negatief oordeel over de opvatting van de arts dat zij de levensbeëindiging ook had kunnen uitvoeren wanneer de patiënte tegen haar zou hebben gezegd dat ze dat niet wilde (r.o. 5.10 in RTG Den Haag 24 juli 2018, ECLI:NL:TGZRSGR: 2018:165).

14. R.o. 5.3 .2 in Rb. Den Haag 11 september 2019, ECLI:NL:RBDHA: 2019:9506.

15. R.o. 4.4 .4 in Rb. Den Haag 11 september 2019, ECLI:NL:RBDHA: 2019:9506. 
van deze specifieke rechtsopvatting van de rechtbank over de afwezigheid van de juridische plicht om de levensbeëindiging met de patiënte te bespreken.

Uit de parlementaire geschiedenis waarnaar de rechtbank en de Hoge Raad verwijzen, kan ook niet worden afgeleid dat de wetgever aan artsen de bevoegdheid heeft willen toekennen om de levens te beëindigen van psychogeriatrische patiënten zonder deze patiënten te informeren over de voorgenomen levensbeëindiging en zonder te proberen om van deze patiënten toestemming voor de levensbeëindiging te krijgen. Er zijn geen passages in de Kamerstukken waarin de bevoegdheid van de arts wordt besproken om op basis van een schriftelijke wilsverklaring het leven van een patiënt te beëindigen zonder daarover met de patiënt te overleggen. ${ }^{16}$

De bevoegdheid van de arts om zonder voorafgaand overleg het leven van een patiënt te beëindigen, zou een uitzondering zijn op de informatieplicht van de arts en het beslissingsrecht van de patiënt, zoals die plicht en dat recht zijn geregeld in de wettelijke bepalingen waarnaar het Regionaal Tuchtcollege in zijn hiervoor aangehaalde overweging verwijst. Vanwege dat uitzonderlijke karakter vereist de bevoegdheid om het leven van een patiënt te beëindigen zonder de levensbeëindiging met de patiënt te bespreken een bijzondere rechtvaardiging die niet in de tekst of de parlementaire geschiedenis van de $\mathrm{Wtl}$ is terug te vinden, en ook niet in de overwegingen van de rechtbank en de Hoge Raad.

\section{Informatie, toestemming, zelfbeschikking}

De rechtbank Den Haag gaat (net als de Hoge Raad) niet in op de rechtsopvatting van het Regionaal Tuchtcollege en het Centraal Tuchtcollege over de juridische plicht van de arts om met de patiënt over levensbeëindiging te praten en te proberen daarvoor toestemming van de patiënt te krijgen. Volgens het Regionaal Tuchtcollege is deze plicht gebaseerd op de Wet op de geneeskundige behandelingsovereenkomst (WGBO). Op grond van artikel 7:448 lid $1 \mathrm{BW} / \mathrm{WGBO}$ is de arts verplicht om de patiënt te informeren over een voorgenomen behandeling en op grond van artikel 7:450 lid 1 BW/WGBO kan de arts een behandeling slechts uitvoeren wanneer de patiënt daarvoor toestemming geeft.

Volgens de tuchtcolleges bestaat er dus wel een op de wet gebaseerde plicht voor de arts om met zijn patiënt te bespreken wat de patiënt wil. De plicht om de patiënt te informeren en met hem te overleggen wordt in een wetsvoorstel uit 2018 verduidelijkt door wijziging van artikel 7:448 lid $1 \mathrm{BW}$ met de zinsnede: '(de arts) licht de patiënt op duidelijke wijze in, die past bij zijn bevat-

16. Zie de noten in HR 21 april 2020, ECLI:NL:HR:2020:712 en de bijlage HR 21 april 2020, ECLI:NL:HR:2020:768 met een overzicht van relevante passages uit de Kamerstukken. tingsvermogen, en overlegt tijdig met de patiënt'. ${ }^{17}$ Deze informatie- en overlegplicht van de arts geldt volgens de tuchtcolleges ook bij de beslissing over het beëindigen van het leven van patiënten met dementie. De arts moet de patiënt informeren over de voorgenomen levensbeëindiging en met de patiënt overleggen om te proberen daarvoor toestemming van de patiënt te krijgen. De arts moet dat doen op een wijze die past bij het bevattingsvermogen van de patiënt. De rechtbank Den Haag en de Hoge Raad hebben niet aangegeven waarom deze rechtsopvatting van de tuchtcolleges onjuist is.

In verband met de beoordeling van wilsonbekwaamheid zijn de informatieplicht en het toestemmingsvereiste uit de WGBO uitgewerkt in een richtlijn van de KNMG met de titel Stappenplan bij beoordeling van milsbekmaamheid. ${ }^{18}$ Uit dit Stappenplan blijkt dat de arts de patiënt er allereerst over moet informeren dat de arts de wilsbekwaamheid van de patiënt gaat onderzoeken ter zake van een specifieke beslissing. Dat onderzoek moet vervolgens plaatsvinden in de vorm van een gesprek met de patiënt waarin de arts onderzoekt of de patiënt in staat is om zijn wil te uiten ten aanzien van deze beslissing. De arts moet de patiënt zo veel mogelijk over de beslissing informeren om hem de gelegenheid te geven zelf de beslissing te nemen: het verkrijgen van informed consent is het primaire doel van het gesprek volgens het Stappenplan (stap 4, 5 en 6). De arts moet ook zijn beoordeling van de wilsonbekwaamheid met de patiënt bespreken en de patiënt zo veel mogelijk betrekken bij de uitvoering van de beslissing. Dat laatste moet de arts ook doen wanneer hij tot het oordeel is gekomen dat de patiënt wilsonbekwaam is ter zake van de beslissing. ${ }^{19}$

De logica van het Stappenplan is dat de arts een gesprek met de patiënt moet voeren over een specifieke beslissing en hem over deze beslissing moet informeren om de wilsbekwaamheid van de patiënt ter zake van deze beslissing te kunnen beoordelen. Daarbij moet de arts zo veel mogelijk proberen om de patiënt zelf te laten beslissen op grond van de door de arts verstrekte informatie over de voorgenomen beslissing. De informatieplicht en het beslissingsrecht van artikel 7:448 lid 1 en 7:450 lid 1 BW/WGBO zijn de wettelijke basis van deze logica van het Stappenplan. Artikel 8 EVRM is de mensenrechtelijke grondslag daarvan en bij beslissingen over euthanasie is dat ook artikel 2 EVRM. In zijn hiervoor aangehaalde overweging verwijst het Regionaal Tuchtcollege naar het recht van de patiënte om over haar eigen leven

17. Kamerstukken // 2017/18, 34994, nr. 2. Dit is volgens de toelichting een codificatie van bestaande opvattingen over de relatie tussen arts en patiënt: Kamerstukken // 2017/18, 34994, nr. 3, p. 3-6. Het wetsvoorstel is op 4 juni 2019 door de Eerste Kamer aangenomen (Handelingen / 2018/19, nr. 33, item 5) en op 1 januari 2020 in werking getreden.

18. Dit Stappenplan is als bijlage opgenomen in de tekst Implementatie van de WGBO. Van wet naar praktijk. Deel 2 Informatie en Toestemming uit 2004, p. 117 e.v. Deze tekst is te vinden op www.knmg.nl.

19. Stap 11 en 16. Zie ook Implementatie van de WGBO. Van wet naar praktijk. Deel 2 Informatie en Toestemming, p. 116 over de informatieplicht van de arts ten opzichte van wilsonbekwame patiënten. 
te beschikken. Dit zelfbeschikkingsrecht is de mensenrechtelijke basis van de WGBO en het Stappenplan en de daarin geregelde informatieplicht van de arts en het beslissingsrecht van de patiënt.

Het Internationaal Verdrag inzake de Rechten van Personen met een Handicap (IVRPH) heeft dezelfde strekking. Niet alleen bevat dit verdrag bepalingen die het recht op leven en de persoonlijke levenssfeer van patiënten met een handicap beschermen (art. 10 en 22 IVRPH), maar ook bepaalt dit verdrag dat personen met een handicap handelingsbekwaam zijn en dat zij zo veel mogelijk in staat moeten worden gesteld om hun handelingsbekwaamheid uit te oefenen (art. 12 IVRPH). De strekking van het verdrag is de bescherming van de autonomie van mensen met een handicap en het verdrag is van toepassing op mensen met langdurige mentale en intellectuele beperkingen (art. 1 IVRPH). Daaronder vallen ook mensen met dementie. ${ }^{20}$

Het Stappenplan beschermt het zelfbeschikkingsrecht van patiënten, omdat het Stappenplan op de veronderstelling berust dat patiënten wilsbekwaam zijn en daarom zelf kunnen beslissen, totdat in een gesprek over de voorgenomen beslissing is vastgesteld dat zij dat niet meer kunnen ter zake van de besproken beslissing. ${ }^{21} \mathrm{De}$ procedure van het Stappenplan is er niet in de eerste plaats op gericht om patiënten wilsonbekwaam te verklaren, maar om patiënten zo veel mogelijk de gelegenheid te geven om zelf te beslissen conform het zelfbeschikkingsrecht van de patiënt. Om die reden moet de arts de patiënt informeren over de voorgenomen beslissing, zodat de patiënt op basis van die informatie de gelegenheid krijgt om zelf te beslissen. Wanneer de patiënt daartoe op grond van de gegeven informatie niet in staat is, is de patiënt wilsonbekwaam ter zake van deze specifieke beslissing.

Ook volgens de Hoge Raad moet een arts zich inspannen om betekenisvol te communiceren met de patiënt in verband met de wettelijke eisen dat de patiënt een vrijwillig en weloverwogen verzoek moet doen tot levensbeëindiging en ondraaglijk en uitzichtloos moet lijden. ${ }^{22}$ Deze inspanningsverplichting van de arts kan eveneens worden afgeleid uit het zelfbeschikkingsrecht van de patiënt. De verplichting van de arts om zich in te spannen tot betekenisvolle communicatie met de patiënt

20. Committee on the Rights of Persons with Disabilities 8 mei 2017, CRPD/C/CAN/CO/1, p. 3, te vinden op https://tbinternet.ohchr.org.

21. Implementatie van de WGBO. Van wet naar praktijk. Deel 2 Informatie en Toestemming, p. 116. Zie over dit gezondheidsrechtelijke uitgangspunt uitgebreid I.M. Hein, J. Raymaekers, E. Kres \& B.J.M. Frederiks, 'Wilsbekwaamheid bij mensen met een verstandelijke beperking', Tijdschrift voor Psychiatrie, 61 (2019) 11, p. 766-771 met bespreking van de uitgangspunten van het Internationaal Verdrag inzake de Rechten van Personen met een Handicap (IVRPH), de Wet op de geneeskundige behandelingsovereenkomst (WGBO), de Wet bijzondere opnemingen in psychiatrische ziekenhuizen (Wet Bopz) en de Wet zorg en dwang psychogeriatrische en verstandelijk gehandicapte cliënten (Wzd). Zie ook A.M. Ruissen, G. Meynen \& G.A.M. Widdershoven, ‘Perspectieven op wilsbekwaamheid in de psychiatrie: cognitieve functies, emoties en waarden', Tijdschrift voor Psychiatrie, 53 (2011) 7, p. 405-414.

22. R.o. 4.7.2 in HR 21 april 2020, ECLI:NL:HR:2020:712. moet erop zijn gericht om de patiënt zo veel mogelijk de gelegenheid te geven zich betekenisvol te uiten over de vraag of zijn lijden ondraaglijk is en zijn leven moet worden beëindigd.

\section{Het verzwegen voornemen}

De toetsingscommissie, de tuchtcolleges en de rechtbank zijn er in navolging van de arts van uitgegaan dat de patiënte wilsonbekwaam was toen zij werd opgenomen in het verpleeghuis. Volgens de arts was de patiënte 'ergens in de loop van het jaar voor overlijden' wilsonbekwaam geworden. ${ }^{23}$ Deze instanties hebben de juistheid van dat standpunt van de arts niet getoetst aan het Stappenplan van de KNMG, de door de Hoge Raad erkende inspanningsverplichting en het zelfbeschikkingsrecht van de patiënte. Het standpunt van de arts dat de patiënte al wilsonbekwaam was bij opname in het verpleeghuis, houdt in dat de patiënte na de opname niet meer haar zelfbeschikkingsrecht kon uitoefenen over haar eigen leven. Dat de arts de wilsonbekwaamheid van de patiënte heeft kunnen vaststellen zonder gesprek met de patiënte over de voorgenomen beslissing om haar leven te beëindigen, staat op gespannen voet met de richtlijn van de KNMG, artikel 7:448 lid 1 en 7:450 lid $1 \mathrm{BW} / \mathrm{WGBO}$, artikel 2 en 8 EVRM en artikel 10, 12 en 22 IVRPH.

Volgens het Stappenplan had de wilsbekwaamheid van de patiënte ter zake van de beslissing om haar leven te beëindigen moeten worden onderzocht in een gesprek van de arts met de patiënte waarin de arts de patiënte over deze beslissing had geïnformeerd en had geprobeerd om toestemming van de patiënte te krijgen voor de levensbeëindiging. Alle beoordelende instanties zijn ervan uitgegaan dat de arts niet een dergelijk gesprek met de patiënte heeft gevoerd. De arts heeft zich in de verschillende procedures juist nadrukkelijk op het standpunt gesteld dat zij welbewust heeft nagelaten om de patiënte te informeren over de voorgenomen levensbeëindiging en te proberen om daarvoor toestemming van de patiënte te krijgen. Dit standpunt van de arts had tot de conclusie moeten leiden dat de arts niet heeft kunnen vaststellen dat de patiënte wilsonbekwaam was ter zake van de beslissing om haar leven te beëindigen. ${ }^{24}$ Uit het medisch dossier van de arts blijkt bovendien dat de patiënte na opname in het verpleeghuis wel in staat was om specifieke vragen over haar levenseinde te beantwoorden en daarover haar wil te uiten. Zo verklaarde ze op de vraag van een consulent van de Levenseindekliniek of ze dood wilde dat ze dat nog niet wilde

23. Zie de verklaring van de arts, weergegeven in Oordeel 2016-85 van de toetsingscommissie.

24. Vgl. P. Moleman, M.G.M. Olde Rikkert \& F. Visser, 'Uitgangspunt Hoge Raad dat iemand met voortgeschreden dementie geen wil heeft niet houdbaar', Volkskrant 5 mei 2020. Olde Rikkert is hoogleraar Geriatrie en hoofd van het Radboudumc Alzheimer Centrum, en voor zover ik kan nagaan de eerste psychogeriatrisch deskundige die zich in het openbaar heeft uitgelaten over deze zaak. 
omdat ze het nog niet zo erg vond. Uit de notitie hierover in het medisch dossier kan worden afgeleid dat betekenisvolle communicatie over haar levenseinde wel mogelijk was met de patiënte. Ze kon daarbij ook aangeven dat ze niet ondraaglijk leed ('het is nog niet zo erg'). ${ }^{25}$ Wanneer de patiënte vervolgens zou zijn geïnformeerd over het voornemen van de arts om haar leven te beëindigen, had ze kunnen herhalen wat ze tegen de consulent van de Levenseindekliniek heeft gezegd: dat wil ik niet, want het is nog niet zo erg. ${ }^{26}$

Het zou ook mogelijk zijn geweest dat de arts in een gesprek met de patiënte over het voornemen om haar leven te beëindigen, had kunnen vaststellen dat de patiente niet meer in staat was om haar wil daarover te uiten. In dat geval had de arts naar aanleiding van het gesprek met de patiënte kunnen besluiten om gevolg te geven aan haar schriftelijke wilsverklaring. Er was in dit geval geen goede reden om niet overeenkomstig het Stappenplan een gesprek met de patiënte te voeren waarin de patiënte werd geïnformeerd over het voornemen van de arts om haar leven te beëindigen, zodat de patiënte de gelegenheid had gekregen om haar wil over dat voornemen te uiten en zelf te beslissen.

Uit artikel 2 lid $2 \mathrm{Wtl}$ volgt de wettelijke eis dat eerst had moeten worden vastgesteld dat de patiënte niet meer in staat was om haar wil te uiten over de beslissing om haar leven te beëindigen, voordat de arts gevolg had kunnen geven aan het schriftelijke verzoek van de patiente. De wettelijke eis om de patiënte te informeren over de voorgenomen levensbeëindiging en te proberen daarvoor toestemming van de patiënte te krijgen, is eveneens gebaseerd op de informatieplicht van de arts en het beslissingsrecht van de patiënte uit artikel 7:448 lid 1 en artikel 7:450 lid 1 BW/WGBO. Deze wettelijke eis kan ook worden gebaseerd op artikel 47 lid 1 Wet BIG.

Het argument van de arts om de patiënte niet over de voorgenomen levensbeëindiging te informeren, was dat de arts 'een nog grotere onrust en agitatie' bij de patiënte wilde voorkomen. ${ }^{27}$ Dat kan echter geen argument zijn om de wilsonbekwaamheid van de patiënte niet te onderzoeken in een gesprek met de patiënte waarin de patiënte over de voorgenomen levensbeëindiging wordt geïnformeerd. Bovendien zouden onrust en agitatie begrijpelijke reacties zijn geweest wanneer de patiënte inderdaad nog niet dood wilde en in staat was om haar wil hierover te uiten. Onrust en agitatie vanwege de wil om verder te leven, zijn juist zwaarwegende redenen om af te zien van levensbeëindiging, zoals het Regionaal Tuchtcollege nadrukkelijk aangeeft in zijn hiervoor aangehaalde overweging. ${ }^{28}$

25. R.o. 2.13 in RTG Den Haag 24 juli 2018, ECLI:NL:TGZRSGR:2018:165

26. Zie ook de bespreking van de verschillende negatieve wilsverklaringen van de patiënte tegenover haar artsen in de beoordeling door de toetsingscommissie (Oordeel 2016-85).

27. R.o. 5.3 .7 in Rb. Den Haag 11 september 2019, ECLI:NL:RBDHA 2019:9506

28. R.o. 5.13 in RTG Den Haag 24 juli 2018, ECLI:NL:TGZRSGR:2018:165.
Ook de Hoge Raad geeft nadrukkelijk aan dat het verzoek uit de schriftelijke verklaring niet kan worden gevolgd wanneer niet zonder meer kan worden vastgesteld dat zich daadwerkelijk de situatie voordoet dat een patiënt niet meer in staat is om zijn wil te vormen en te uiten over de levensbeëindiging. ${ }^{29}$ Ook als wel kan worden vastgesteld dat deze situatie zich voordoet, kunnen volgens de Hoge Raad negatieve reacties van de patiënt (contra-indicaties) eraan in de weg staan dat aan het schriftelijke verzoek van de patiënt gevolg kan worden gegeven. ${ }^{30}$ Daarom had de patiënte juist wel moeten worden geinformeerd over het voornemen van de arts om haar leven te beëindigen, zodat de patiënte de gelegenheid had gekregen om haar onrust en agitatie over dat voornemen te uiten. Bij die gelegenheid had de arts kunnen onderzoeken of de patiënte in staat was om haar wil te uiten over de voorgenomen levensbeëindiging en daarover zelf een beslissing te nemen. Afhankelijk van de reacties van de patiënte had de arts wel of niet gevolg kunnen geven aan de schriftelijke wilsverklaring van de patiënte.

\section{Mensenrechten van psychogeriatrische patiënten}

Het verzwijgen van het voornemen om het leven van de patiënte te beëindigen, was volgens het Regionaal Tuchtcollege in strijd met het recht van de patiënte om over haar eigen leven te beschikken. Door het verzwijgen van de voorgenomen levensbeëindiging kon de patiente haar zelfbeschikkingsrecht niet uitoefenen ten aanzien van haar eigen levenseinde. Dat zelfbeschikkingsrecht heeft een hecht mensenrechtelijk fundament in artikel 2 en 8 EVRM en artikel 10, 12 en 22 IVRPH. Over het verzwijgen van het voornemen en de toelaatbaarheid daarvan in het licht van deze mensenrechtelijke verdragsbepalingen zegt de Hoge Raad in beide arresten niets. Dat is opmerkelijk in een zaak die gaat over het recht van de patiënte om over haar eigen leven te beschikken. ${ }^{31}$

In de door de Hoge Raad aangehaalde Kamerstukken wordt evenmin iets gezegd over de toepasselijke bepalingen van het EVRM en het IVRPH. ${ }^{32}$ Uit de aangehaalde Kamerstukken blijkt niet dat de wetgever aan deze verdragsbepalingen heeft getoetst of artsen de levens van psychogeriatrische patiënten mogen beëindigen op grond van hun schriftelijke wilsverklaringen

29. R.o. 4.3.2 in HR 21 april 2020, ECLI:NL:HR:2020:712.

30. R.o. 4.5.3 in HR 21 april 2020, ECLI:NL:HR:2020:712. Zie over contraindicaties bij patiënten met dementie p. 43 van de EuthanasieCode 2018 en p. 27 van de Code of Practice 2015 van de toetsingscommissies (te vinden op www.euthanasiecommissie.nl).

31. In gelijke zin T.M. Schalken in punt 7 en 8 van zijn noot onder HR 21 april 2020, ECLI:NL:HR:2020:712, GJ 2020/70. Zie ook A.C. Hendriks, 'Schriftelijk euthanasieverzoek bij vergevorderde dementie als basis', Rechtsgeleerd Magazijn THEMIS, 2020-3, p. 130 en 132.

32. Zie de bijlage met het overzicht van passages uit de Kamerstukken, HR 21 april 2020, ECLI:NL:HR:2020:768. 
zonder gesprekken met deze patiënten te voeren waarin zij worden geïformeerd over het voornemen van de arts om hun leven te beëindigen. Toetsing aan het IVRPH was tijdens de parlementaire behandeling van de Wtl ook niet mogelijk, omdat het VN-verdrag op 13 december 2006 in New York werd aanvaard door de Algemene Vergadering van de Verenigde Naties. Dat was meer dan vier jaar en negen maanden na de inwerkingtreding van de Wtl op 1 april 2002.

In de aangehaalde Kamerstukken ontbreken ook beschouwingen over de KNMG-richtlijn (het Stappenplan) uit 2004 en de grondslag van het Stappenplan in de informatieplicht en het beslissingsrecht uit de WGBO. De rechtspraak van het EHRM over de positieve verplichtingen van staten om mensenrechten van bijzonder kwetsbare personen in de gezondheidszorg te beschermen, kwam pas tot ontwikkeling na de inwerkingtreding van de $\mathrm{Wtl} .{ }^{33}$ De parlementaire geschiedenis van de $\mathrm{Wtl}$ kan daarom geen uitsluitsel geven over de rechtsvraag in hoeverre de bevoegdheid van artsen om levens van psychogeriatrische patiënten te beëindigen zonder dat eerst met deze patiënten te bespreken in overeenstemming is met gezondheidsrechtelijke regelingen en mensenrechtenverdragen.

Mensenrechten bepalen de juridische grenzen van de bevoegdheid van artsen om de levens van patiënten te beëindigen. Het is daarom belangrijk dat het voor artsen duidelijk is dat zij bij hun levensbeëindigende handelen aan de mensenrechten van hun patiënten zijn gebonden.

Door te zwijgen over de mensenrechten uit het EVRM en het IVRPH wekt de Hoge Raad ten onrechte de indruk dat artsen de bevoegdheid hebben om de levens van psychogeriatrische patiënten te beëindigen zonder daarover met deze patiënten te overleggen. Het mensenrechtelijke argument tegen een bevoegdheid om zonder voorafgaand overleg het leven van een patiënt te beëindigen, is dat door de uitoefening van die bevoegdheid het recht van patiënten om over hun eigen leven te beschikken kan worden geschonden. Door het achterwege laten van overleg krijgen zij niet de gelegenheid om hun wil te vormen en te uiten over de beslissing om hun leven te beëindigen en daarover zelf te beslissen. Dat is het mensenrechtelijke argument van het Regionaal Tuchtcollege om het handelen van de arts in deze zaak als onzorgvuldig te kwalificeren.

\section{De tuchtrechter voor de strafrechter}

De Hoge Raad heeft in zijn arrest over de uitspraken van de tuchtcolleges niet gemotiveerd waarom de verwijzing van het Regionaal Tuchtcollege naar het recht van de patiënte om over haar leven te beschikken onjuist is. De rechtbank Den Haag heeft evenmin gemotiveerd waarom dit mensenrechtelijke argument van het Regio-

33. Zie r.o. 103 e.v. in EHRM 31 januari 2019, No. 78103/14 (Fernandes de Oliveira/Portugal) met verwijzing naar vaste rechtspraak. naal Tuchtcollege onjuist is. Dat geldt ook ten aanzien van de gezondheidsrechtelijke argumenten van het tuchtcollege. Daardoor wijken de Hoge Raad en de rechtbank Den Haag af van rechtspraak van de civiele kamer van de Hoge Raad over de verhouding tussen de rechter en de tuchtrechter. In een arrest uit 2002 overwoog deze kamer:

'Bij de beoordeling van de motiveringsklacht van onderdeel 5.2 wordt vooropgesteld dat de rechter, indien hij bij de beoordeling van medisch handelen van een arts komt tot een oordeel dat afwijkt van het oordeel dat de tuchtrechter heeft gegeven naar aanleiding van een klacht met betrekking tot datzelfde medisch handelen, zijn oordeel zodanig dient te motiveren dat dit, ook in het licht van de beoordeling door de tuchtrechter, voldoende begrijpelijk is. Daarbij valt in het bijzonder te denken aan een motivering met behulp van verklaringen van een of meer, zo nodig door de rechter te benoemen, deskundigen.' ${ }^{34}$

Uit deze overweging van de civiele kamer van de Hoge Raad kan worden afgeleid dat de rechtbank Den Haag had moeten motiveren waarom zij de uitspraak van het Regionaal Tuchtcollege niet volgde op het specifieke punt van de verplichting van de arts om met de patiënte te praten over het voornemen om haar leven te beëindigen. De rechtbank had die afwijking van het oordeel van de tuchtrechter op een zodanige wijze moeten motiveren dat haar beslissing in het licht van de aangehaalde overweging van het Regionaal Tuchtcollege voldoende begrijpelijk zou zijn geweest. Een dergelijke motivering ontbreekt in het vonnis van de rechtbank en ook in de arresten van de Hoge Raad. In deze arresten ontbreekt ook een motivering waarom de strafkamer van de Hoge Raad het civiele arrest niet volgt. ${ }^{35}$

De Hoge Raad geeft echter wel aan dat de wetgever heeft gekozen voor een wettelijk stelsel waarbinnen de beoordeling van euthanasie plaatsvindt door gespecialiseerde toetsingscommissies aan de hand van inzichten en normen van medische professionals. In dat stelsel moet de strafrechter zich volgens de Hoge Raad terughoudend opstellen bij de beantwoording van de vraag welk medisch handelen aanvaardbaar is. Aangezien artsen ook aan het medisch tuchtrecht zijn onderworpen, is strafvervolging volgens de Hoge Raad niet steeds de meest aangewezen reactie op mogelijk onzorgvuldig handelen van artsen bij euthanasie. ${ }^{36}$ Wanneer volgens deze opvatting van de Hoge Raad zou zijn gehandeld in deze zaak, zouden de uitspraken van het Regionaal Tuchtcollege en het Centraal Tuchtcollege richtinggevend zijn geweest voor artsen die overwegen om de levens van psychogeriatrische patiënten te beëindigen.

34. R.o. 3.6.3 in HR 12 juli 2002, ECLI:NL:HR:2002:AE1532, NJ 2003/151 m.nt. F.C.B. van Wijmen. Zie ook r.o. 3.3.2 in HR 22 september 2017 , ECLI:NL:HR:2017:2452.

35. Zie hierover punt 5 en 6 in de noot van Hubben onder HR 21 april 2020, ECLI:NL:HR:2020:713, GJ 2020/71.

36. R.o. 4.11.2 en 4.11.3 in HR 21 april 2020, ECLI:NL:HR:2020:712. 
De vereiste terughoudendheid van de strafrechter impliceert wat de civiele kamer van de Hoge Raad expliciet heeft beslist: de strafrechter kan alleen met een begrijpelijke motivering afwijken van het oordeel van de tuchtrechter. De rechtbank is echter zonder motivering ten aanzien van de aangehaalde overweging van het Regionaal Tuchtcollege en zonder raadpleging van deskundigen afgeweken van het oordeel van de tuchtrechter op het specifieke punt van de verplichting om met de patiënte over euthanasie te praten. De rechtbank heeft zich daarbij gebaseerd op haar eigen oordeel over de coherentie van wilsuitingen van de patiënte. ${ }^{37}$ Ook de Hoge Raad gaat ervan uit dat de rechtbank zelf heeft vastgesteld dat de patiënte niet meer in staat was om een coherente wil te uiten. ${ }^{38}$ De vaststelling daarvan is echter bij uitstek een kwestie die de strafrechter had moeten baseren op de verklaring van een psychogeriatrisch deskundige die zelf de patiënte heeft gezien en onderzocht. Deze deskundige had de wilsonbekwaamheid van de patiënte moeten onderzoeken in een gesprek met de patiënte waarin de deskundige de patiënte had moeten informeren over het voornemen om haar leven te beëindigen, zodat de patiënte de gelegenheid had gekregen om daarover haar wil te uiten en de deskundige had kunnen beoordelen of de patiënte daartoe in staat was.

\section{Beoordeling door deskundigen}

De wil en de wilsbekwaamheid van psychogeriatrische patiënten moeten worden beoordeeld door deskundigen. Dat is ook het uitgangspunt van de (niet door de Hoge Raad besproken) Wet zorg en dwang psychogeriatrische en verstandelijk gehandicapte cliënten (Wzd). Deze wet is sinds 1 januari 2020 de regelgeving omtrent dwangbehandeling en dwangmedicatie. Volgens het Regionaal Tuchtcollege is deze regelgeving relevant bij beslissingen over het beëindigen van de levens van patiënten met dementie. ${ }^{39}$ Artikel 3 lid $2 \mathrm{Wzd}$ bepaalt dat de wilsonbekwaamheid van psychogeriatrische patiënten moet worden vastgesteld door een deskundige, niet zijnde de bij de zorg betrokken arts, overeenkomstig de daarvoor gangbare richtlijnen. Volgens artikel 3 lid $3 \mathrm{Wzd}$ moet de behandelende arts het oordeel van de deskundige en de beslissing waarop dat oordeel betrekking heeft schriftelijk vastleggen, zodat toezicht door de Inspectie Gezondheidszorg en Jeugd mogelijk is. ${ }^{40}$

De Wzd is niet rechtstreeks van toepassing bij euthanasie, omdat euthanasie niet als een vorm van dwang kan

37. R.o. 5.3.2 in Rb. Den Haag 11 september 2019, ECLI:NL:RBDHA: 2019:9506.

38. R.o. 5.5.2 in HR 21 april 2020, ECLI:NL:HR:2020:712.

39. R.o. 5.13 in RTG Den Haag 24 juli 2018, ECLI:NL:TGZRSGR:2018:165

40. Artikel 17 lid 1 onder $\mathrm{d}$ Wzd worden uitgelegd volgens deze wet. ${ }^{41}$ De procedure voor de vaststelling van wilsonbekwaamheid uit artikel 3 lid 2 en $3 \mathrm{Wzd}$ kan echter wel worden toegepast bij de beslissing om de schriftelijke wilsverklaring te volgen op grond van artikel 2 lid $2 \mathrm{Wtl}$. Daarvoor moet immers eerst worden vastgesteld dat de patiënt wilsonbekwaam is ter zake van de beslissing om zijn leven te beëindigen. Dat kan worden vastgesteld via overeenkomstige toepassing van artikel 3 lid 2 en $3 \mathrm{Wzd}$ bij de beslissing om de schriftelijke wilsverklaring te volgen: een deskundige, niet zijnde de bij de zorg betrokken arts, moet de wilsonbekwaamheid van de patiënt beoordelen overeenkomstig de daarvoor gangbare richtlijnen, zoals het Stappenplan van de KNMG.

De ratio van deze regeling is dat daardoor de onafhankelijkheid en de deskundigheid van de beoordelingen van wilsonbekwaamheid zijn gewaarborgd. Uit deze ratio kan de overeenkomstige toepassing van artikel 3 lid 2 en $3 \mathrm{Wzd}$ worden afgeleid bij euthanasie. Ook bij euthanasie moet de onafhankelijkheid en de deskundigheid van de beoordeling worden gewaarborgd. De toetsingscommissies, de tuchtrechters en eventueel ook de strafrechters kunnen de betrouwbaarheid van de beoordelingen door onafhankelijke deskundigen achteraf toetsen aan de gangbare richtlijnen en de schriftelijke verslagen van deze deskundigen over de wilsonbekwaamheid van de patiënt.

Ook de Hoge Raad benadrukt het vereiste dat in gevallen van levensbeëindiging bij mensen met dementie de consultatie op grond van artikel 2 lid 1 onder e Wtl moet worden uitgevoerd door 'een onafhankelijke arts met een specifieke deskundigheid ter zake'. De Hoge Raad voegt daaraan toe dat in dit soort zaken aanleiding bestaat om twee onafhankelijke deskundigen te consulteren. ${ }^{42}$ De EuthanasieCode 2018 van de toetsingscommissies schrijft nadrukkelijk voor dat de wilsbekwaamheid van een patiënt met dementie in een late fase moet worden beoordeeld door een onafhankelijke arts met deskundigheid op het gebied van ouderengeneeskunde. ${ }^{43}$ Het vereiste van een onafhankelijke beoordeling is voor het eerst geformuleerd in het Chabotarrest uit 1994, waarin de Hoge Raad angaf dat de beslisvaardigheid van een psychiatrisch patiënt moet worden beoordeeld door een onafhankelijke deskundige die zelf de patiënt ziet en onderzoekt. ${ }^{44}$

In de zaak van de verpleeghuisarts was de tweede SCEN-arts een 'internist in ruste'. ${ }^{45}$ Aan de hand van het vereiste van specifieke deskundigheid had de vraag

41. Zie hierover de brief van minister De Jonge aan de Eerste Kamer van 28 augustus 2018 over euthanasie en de Wzd en het verslag van het schriftelijk overleg over deze brief, Kamerstukken / 2018/19, 31996, G.

42. R.o. 4.9 en 6.1 in HR 21 april 2020, ECLI:NL:HR:2020:712.

43. EuthanasieCode 2018, p. 43-44, te vinden op www.euthanasiecommissie.nl. Zie ook p. 28 van de Code of Practice 2015 van de toetsingscommissies. Ouderengeneeskunde is een erkend medisch specialisme in de zin van artikel 14 Wet BIG (Besluit specialisme ouderengeneeskunde, Stcrt. 2020, 14100). Meer informatie hierover is te vinden op www.knmg.nl en www.verenso.nl.

44. R.o. 6.3.3 in HR 21 juni 1994, ECLI:NL:HR:1994:AD2122, NJ 1994/656 m.nt. T.M. Schalken (Chabot).

45. R.o. 2.21 in RTG Den Haag 24 juli 2018, ECLI:NL:TGZRSGR:2018:165. 
moeten worden gesteld welke deskundigheid deze gepensioneerde internist had op het terrein van de ouderengeneeskunde. Ook had de vraag moeten worden gesteld of deze internist de beoordeling van de wilsbekwaamheid van de patiënte heeft uitgevoerd overeenkomstig de daarvoor gangbare richtlijnen. De eerste SCEN-arts was een psychiater van wie evenmin is vastgesteld dat hij specifieke deskundigheid ter zake van ouderengeneeskunde had en zijn beoordeling overeenkomstig de daarvoor gangbare richtlijnen heeft uitgevoerd. ${ }^{46}$

\section{Conclusie: euthanasie moet met de patiënt worden besproken}

Uit de overwegingen van de Hoge Raad kan de conclusie worden getrokken dat de euthanasiewens en de wilsbekwaamheid bij patiënten met dementie in de regel door twee onafhankelijke artsen met deskundigheid ter zake van ouderengeneeskunde moeten worden onderzocht. Deze eis van de Hoge Raad is strenger dan de eis die het Regionaal Tuchtcollege in de hiervoor aangehaalde overweging stelt (de arts moet zelf met de patiënt over euthanasie praten) en ook strenger dan artikel 3 lid $2 \mathrm{Wzd}$, op grond waarvan een onderzoek door één onafhankelijke deskundige volstaat voor de beoordeling van wilsonbekwaamheid. In ieder geval kan worden vastgesteld dat de eisen van het Regionaal Tuchtcollege en de Hoge Raad elkaar bevestigen en versterken: de voorgenomen levensbeëindiging moet met de patiënt worden besproken door een onafhankelijke arts met deskundigheid ter zake van ouderengeneeskunde om te kunnen bepalen of aan de zorgvuldigheidseisen van artikel 2 lid 1 en $2 \mathrm{Wtl}$ is voldaan.

De eis van de Hoge Raad is gebaseerd op de consultatieeis van artikel 2 lid 1 onder e Wtl. Op grond van deze bepaling moeten ter zake deskundige artsen onderzoeken of is voldaan aan de zorgvuldigheidseisen van artikel 2 lid $1 \mathrm{Wtl}$. Wanneer de behandelende arts de schriftelijke wilsverklaring wil volgen, moeten de onafhankelijke deskundigen ook onderzoeken of de patiënt niet in staat is om zijn wil te uiten ter zake van de beslissing om zijn leven te beëindigen. ${ }^{47}$ Als de patiënt daartoe niet in staat is, kan het schriftelijke verzoek worden beschouwd als een verzoek in de zin van artikel 2 lid 1 onder a $\mathrm{Wtl}$ en kan de arts besluiten om gevolg te geven aan dat verzoek wanneer aan de overige vereisten van artikel 2 lid $1 \mathrm{Wtl}$ is voldaan.

Het is aan de toetsingscommissies om de consultatie-eis door onafhankelijke artsen die ter zake deskundig zijn te stellen in de vorm van duidelijke aanwijzingen voor artsen die levens willen beëindigen van psychogeriatrische patiënten. Bij de beoordelingen van deze levensbeëindigingen moeten de toetsingscommissies de deskundigheid van de consulenten toetsen en zij moeten ook toetsen of deze consulenten de wilsonbekwaamheid van patiënten hebben onderzocht overeenkomstig de richtlijn van de KNMG (het Stappenplan) of een andere gangbare richtlijn.

Dit betekent dat de toetsingscommissies ook moeten toetsen of de consulenten de patiënt hebben geinformeerd over het voornemen om zijn leven te beëindigen, zodat de patiënt de gelegenheid heeft gekregen om zijn wil te uiten ter zake van de beslissing daarover. Dat is immers de kern van een deskundige beoordeling van de wilsonbekwaamheid van de patiënt overeenkomstig de daarvoor gangbare richtlijnen (met name het Stappenplan van de KNMG): de beslissing om het leven van de patiënt te beëindigen moet met de patiënt worden besproken om te kunnen beoordelen of de patiënt in staat is om zijn wil te uiten ter zake van deze beslissing, en de patiënt moet daarbij de gelegenheid krijgen om zelf de beslissing te nemen na te zijn geïnformeerd over de voorgenomen levensbeëindiging. De gezondheidsrechtelijke basis daarvan is de informatieplicht van de arts en het beslissingsrecht van de patiënt uit artikel 7:448 en 7:450 BW/WGBO, artikel 3 Wzd en artikel 47 lid 1 Wet BIG. Deze informatieplicht en dit beslissingsrecht kunnen nader worden uitgewerkt aan de hand van de consultatieplicht uit artikel 2 lid 1 onder e Wtl, de rechtspraak hierover van de Hoge Raad en de EuthanasieCode 2018 van de toetsingscommissies.

Het Stappenplan van de KNMG, de informatieplicht van de arts en het beslissingsrecht van de patiënt hebben ook een hecht mensenrechtelijk fundament in het EVRM en het IVRPH. Het recht op leven en het zelfbeschikkingsrecht behoren tot de meest fundamentele waarden van een democratische samenleving. Het Regionaal Tuchtcollege verwees naar deze waarden met zijn overweging dat de patiënte het recht had om over haar eigen leven te beschikken. Daarmee deed de tuchtrechter wat iedere rechter in een dergelijk geval behoort te doen: mensenrechten beschermen van buitengewoon kwetsbare personen in de gezondheidszorg. ${ }^{48}$
46. R.o. 2.20 in RTG Den Haag 24 juli 2018, ECLI:NL:TGZRSGR:2018:165. De consulent van de Levenseindekliniek was een verpleegkundige (r.o. 2.17 in RTG Den Haag 24 juli 2018, ECLI:NL:TGZRSGR:2018:165) en voldeed om die reden niet aan het vereiste dat consultatie door een onafhankelijke arts moet worden uitgevoerd. Ten aanzien van deze verpleegkundige is ook niet vastgesteld dat hij deskundigheid op het gebied van ouderengeneeskunde had en zijn beoordeling van de wilsbekwaamheid heeft uitgevoerd overeenkomstig de daarvoor gangbare richtlijnen.

47. EuthanasieCode 2018, p. 43-44.
48. R.o. 103 e.v. in EHRM 31 januari 2019, No. 78103/14 (Fernandes de Oliveira/Portugal). 